\title{
Petrophysical Evaluation of Reservoir in A Selected Well $(Z)$ in an Onshore Oil Field $(X)$ in the Niger Delta Basin, Nigeria using Wireline Logs
}

\section{*1IGHODARO, EJ; ${ }^{2}$ OKANIGBUAN, PN; ${ }^{3}$ OKIOTOR, ME; ${ }^{4}$ IDEMUDIA, N}

\author{
${ }^{* 1,4}$ Department of Geology and Petroleum Studies, Western Delta University, Oghara, Delta State, Nigeria \\ ${ }^{2}$ Department of Physical Science (Physics Option), Benson Idahosa University, Ugbor, G.R.A., Benin City, Nigeria \\ ${ }^{3}$ Department of Marine Geology, Nigeria Maritime University, Okerenkoko, Delta State, Nigeria \\ *Correspondence Author Email: ehikacross@gmail.com, +2348038598495
}

\begin{abstract}
The petrophysical properties of a well selected from among the onshore oil fields in the Niger Delta Basin, Nigeria was evaluated using gamma ray log, resistivity log and neutron-density overlay log to analyze for the hydrocarbon potential of the well. Some petrophysical properties of the reservoir rocks and fluid characters such as porosity, shale volume, effective porosity, permeability, and formation resistivity factor, resistivity of water, hydrocarbon saturation, water saturation, and net pay thickness were evaluated. The results show that the volume of shale in each reservoir zone directly affects the effective porosity and the zones. The volume of shale is inversely proportional to the effective porosity, as an increase in the volume of shale will bring about a decrease in effective porosity. On the other hand, permeability is dependent on the effective porosity. Facies type identification of the reservoir sands were also carried out using the wireline log - Gamma Ray Log. Results of the work revealed the presence of hydrocarbon in 10 reservoirs across the well, and the hydrocarbon type was observed to be only oil. Oil/Water contacts occurred at $2288 \mathrm{~m}, 2518 \mathrm{~mm}$, and $2989 \mathrm{~m}$, and the Net Pay Thickness was calculated to be $238 \mathrm{~m}$, that is the total thickness of the hydrocarbon reservoirs.
\end{abstract}

\section{DOI: https://dx.doi.org/10.4314/jasem.v23i5.23}

Copyright: Copyright (C) 2019 Ighodaro et al. This is an open access article distributed under the Creative Commons Attribution License (CCL), which permits unrestricted use, distribution, and reproduction in any medium, provided the original work is properly cited.

Dates: Received: 29 April 2019; Revised: 26 May 2019; Accepted 30 May 2019

Keywords: Petrophysics, Wireline logs, Facies, Reservoir rocks, Pay thickness.

A petroleum system is defined as a natural system that encompasses a pod of active source rock and all related oil and gas, and which includes all the geologic elements and processes that are essential if a hydrocarbon accumulation is to exist. The main processes involved in petroleum formation are the trap formation, generation-migration-accumulation of petroleum and preservation; but in all, timing is essential. In the petroleum system, basically two (2) processes occur. They include: (i) Generationmigration-accumulation of hydrocarbon (ii) Trap formation (iii) The essential elements of a petroleum system include: ((a) Petroleum source rock (b) Reservoir rock (c) A migration pathway (d) Seal rock $€$ Overburden rock. For the purpose of this work, the main focus is going to be on the reservoir component of the petroleum system. A petroleum reservoir is a subsurface formation containing gas, oil and water in varying proportions. These fluids are contained in the pore spaces of rock formations, among the grains of sandstones or in cavities of carbonates. The pore spaces are interconnected so the fluids can move through the reservoir.
Reservoir evaluation is the determination of reservoir properties from logs, cores, geophysical data and pressure transient data. These properties include porosity, permeability, and fluid saturation amongst others. Reservoir evaluation is one of the first set of tasks carried out during exploration for petroleum. Reservoir evaluation can be said to be as old as exploration of petroleum itself, but the various techniques applied have been modified and improved overtime. Thus, a good reservoir is characterized by sufficient porosity to contain the hydrocarbon and permeability to permit their movement. In order to evaluate or characterize a reservoir, various forms of analysis can be considered or carried out. They include: ( a) Petrophysical Analysis ( b) Geophysical Analysis (c ) Geochemical Analysis. Geochemical analysis involves the study of data acquired from fluid geochemistry. Geophysical analysis involves the study of data acquired from geophysical surveys, such as seismic data. While petrophysical analysis encompasses the analysis of well logs run on wireline and drillstring, conventional and special core analysis, mud logging, formation testing and fluid sampling. For the purpose of this work, petrophysical analysis is done on Well " $Z$ " in "X" Field, onshore Niger Delta 
as a case study. Wireline $\log$ s are the only set of data to be considered for this well.

Location of Study Well: "Well Z" is located in "Field $X$ " in the onshore portion of the Niger Delta.

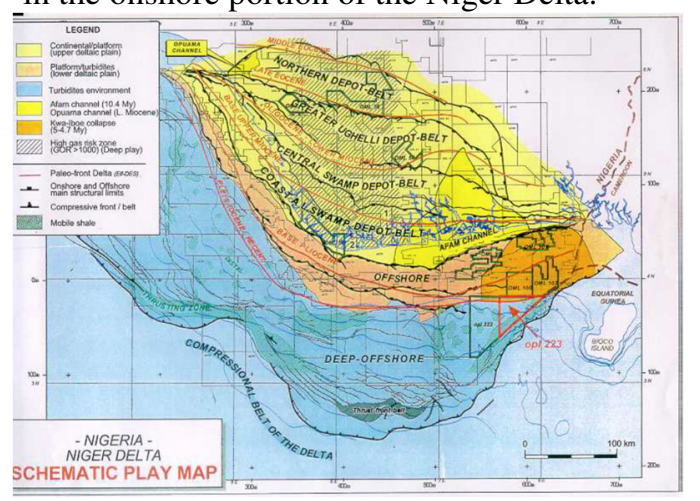

Fig. 1: Map of the Niger Delta showing Depobelts

The Niger Delta Basin is one of the southern Nigeria basins. It lies between longitudes $4^{\circ} \mathrm{E}$ and $8.8^{\circ} \mathrm{E}$ and latitudes $3^{0} \mathrm{~N}$ and $6.5^{\circ} \mathrm{N}$. From the Eocene to the present, the delta has prograded southwestward, forming depobelts that represent the most active portion of the delta at each stage or its development (Doust and Omatsola, 1990). The depobelts in this basin form one of the largest regressive deltas in the world with an area of some $300,000 \mathrm{~km}^{2}$ (Kulke, 1995), sediment volume of $500,000 \mathrm{~km}^{3}$ (Hospers, 1965) and a sediment thickness of over $10 \mathrm{~km}$ in the basin depocenter (Kaplan and Norton 1994). The delta sequence comprises an upward coarsening regressive association of tertiary clastics up to $12 \mathrm{~km}$ thick. It is divided into three (3) gross lithofacies; (iii) marine claystones and shales of unknown thickness, at the base; (ii) alternations of sandstones, silstones and claystones, in which the sand percentage increases upwards; (iii) alluvial sands, at the top.

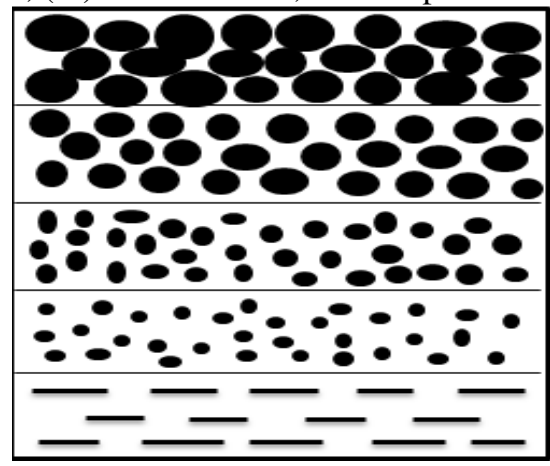

Fig 2. Upward -Coarsening Regression of Clastic Sediments of Niger Delta

The formation of the Southern Nigerian sedimentary basin followed the break-up of the South American and African continents in the Early Cretaceous (Murat, 1972; Burke, 1996). Various lines of geomorphologic, structural, stratigraphic and palaeontologic evidence have been presented to support a rift model (King, 1950; Bullard et al., 1965; Reyment, 1969; Burke et al., 1971, 1972; Fairhead and Green, 1989; Benkhelil, 1989; Guiraud and Bellion, 1995). The stratigraphic history of the region is characterized by three sedimentary phases (Short and Stauble, 1967; Murat, 1972; Obi et al., 2001) during which the axis of the sedimentary basin shifted. These three phases were: (a) The Abakaliki-Benue Phase (Aptian-Santonian) (b) The Anambra-Benin phase (Campanian-Mid Eocene) (c) The Niger Delta phase (late EocenePliocene). The more than 3000 meters of rocks comprising the Asu River Group and the Ezeaku and Awgu formations, were deposited during the first phase in the Abakaliki-Benue Basin, the Benue Valley and the Calabar Flank. The second sedimentary phase resulted from the Santonian folding and uplift of the Abakaliki region and dislocation of the depocenter into the Anambra Platform and Afikpo region. The resulting succession comprises the Nkporo Group, Mamu Formation, Ajali Sandstone, Nsukka Formation, Imo Formation and Ameki Group. The third sedimentary phase credited for the formation of the petroliferous Niger Delta, commenced in the Late Eocene as a result of a major earth movement that structurally inverted the Abakaliki region and displaced the depositional axis further to the south of the Anambra Basin (Obi et al., 2001), resulting in the evolution of the Akata, Agbada and Benin Formations. The evolution of the delta is controlled by pre- and syn-sedimentary tectonics as described by Evamy et al. (1978), Ejedawe (1981), Knox \& Omatsola (1987) and Stacher (1995). In the Delta, rifting diminished altogether in the Late Cretaceous. After rifting ceased, gravity tectonics became the primary deformational process. Shale mobility induced internal deformation occurred in response to two processes. First, shale diapirs formed from loading of poorly compacted, over-pressured prodelta and delta-slope clays (Akata Formation) by the higher density delta-front sand (Agbada Formation). For any given depobelt, gravity tectonics were completed before deposition of the Benin Formation and are expressed in complex structures, including shale diapirs, roll-over anticlines, collapsed growth fault crests, back-to-back features and steeply dipping closed spaced flank faults (Evamy et al 1978). Deposition of the three formations occurred in each of the five off-lapping Siliciclastic Sedimentation Cycle that comprises the Niger Delta. The cycles (depobelts) are defined by synsedimentary faulting that occurred in response to variable rates of subsidence and sediment supply. The interplay of subsidence and supply rates resulted in deposition of discrete depobelts. When further crustal subsidence of the basin could no longer be accommodated, the focus 
of sediment deposition shifted seaward forming a new depobelt. Each depobelt is separate unit that corresponds to a break in regional dip of the delta and is bounded landward by growth faults and seaward by large counter-regional faults or the growth fault of the next seaward belt (Evamy et al 1978).

Table 1: Formations in the Niger Delta area. (Modified from Short

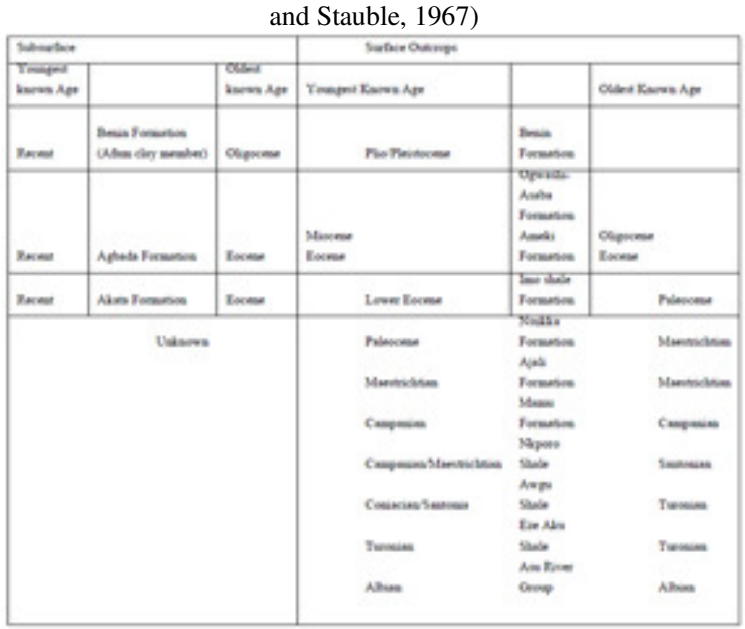

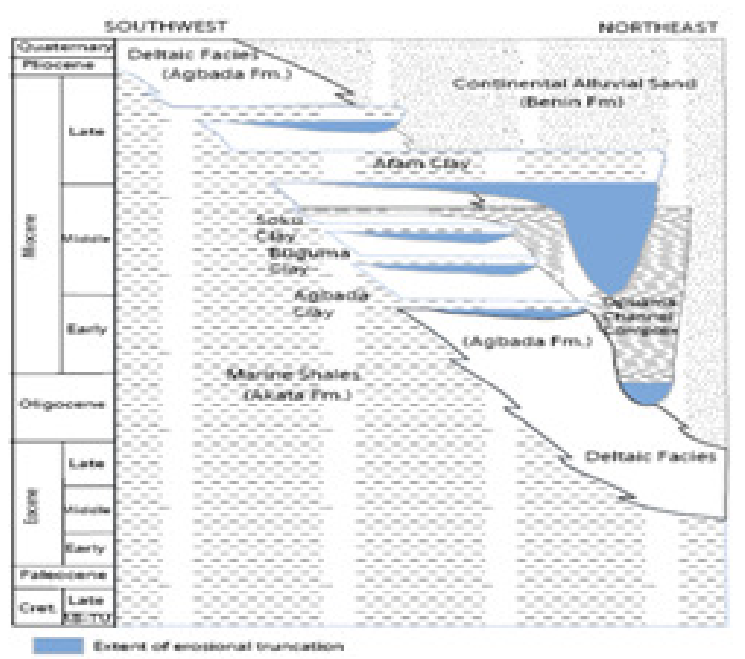

Fig 3: Stratigraphic column showing the three formations of the Niger Delta. Modified from Shannon and Naylor (1989) and Doust and Omatsola (1990)

Five major depobelts are generally recognized, each with its own sedimentation, deformation, and petroleum history. The northern delta province, which overlies relatively shallow basement, has the oldest growth faults that are generally rotational, evenly spaced with increased steepness seaward. The central delta province has depobelts with well-defined structures such as successively deeper roll over crests that shifts seaward for any given growth fault. Lastly, the distal delta province is the most structurally complex due to internal gravity tectonics in the modern continental slope.
The modern Niger Delta is subdivided into three (3) formations based on the evidence of sedimentological and faunal configurations similar to that of the past (Short and Stauble, 1967). The three major subsurface stratigraphic units are; (i) Akata Formation (ii) Agbada Formation (iii) Benin Formation

\section{MATERIALS AND METHOD}

Materials: The primary materials used for the study were wireline logs obtained from Well " $Z$ " in "Field $X$ " of the Niger Delta. The logs contained include; Gamma Ray Log, Density Log, Neutron/Density Cross Plot Log, Resistivity Log

Gamma Ray Log: The Gamma Ray log, commonly given the symbol $G R$ is a continuous measurement of the natural radioactivity emanating from the formations. Principal isotopes emitting radiation are Potassium-40, Uranium, and Thorium (K40, U, Th). Sensitive detectors count the number of gamma rays per unit of time. Once the gamma rays are emitted from an isotope in the formation, they progressively reduce in energy as the result of collisions with other atoms in the rock (compton scattering). Compton scattering occurs until the gamma ray is of such a low energy that it is completely absorbed by the formation. Hence, the gamma ray intensity that the log measures is a function of: (i) The initial intensity of gamma ray emission, which is a property of the elemental composition of the rock. (ii) The amount of compton scattering that the gamma rays encounter, which is related to the distance between the gamma emission and the detector and the density of the intervening material.

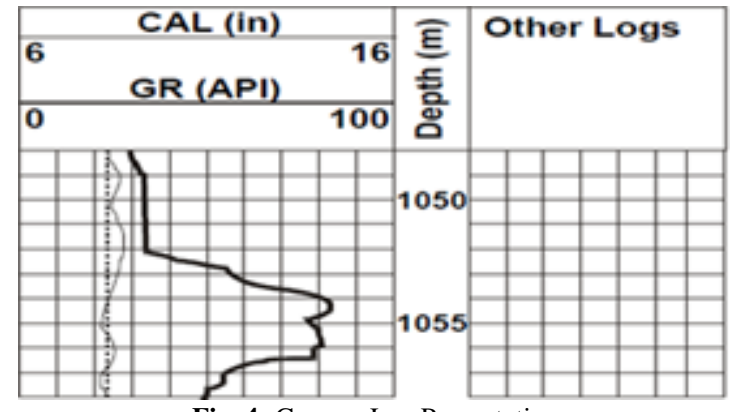

Fig. 4: Gamma Log Presentation

Principal isotopes emitting radiation (Potassium-40, Uranium, and Thorium) are more concentrated in clays; thus higher radioactivity in shales than other formations.

Resistivity Log: The whole of resistivity logging is based upon a few very important equations which relate the resistivity of a formation to the resistivity of the fluids saturating a formation, the porosity of the 
formation and the fractional degree of saturation of each fluid present. Resistivity is a measure of the ability of a formation to resist or conduct electric current.

Density Log: The formation density log measures the bulk density of the formation. Its main use is to derive a value for the total porosity of the formation. It is also useful in the detection of gas-bearing formations and in the recognition of evaporites, oil and gas. The bulk density $(\rho b)$ of a reservoir is the weighted average density of the present pore fluids ( $\rho f l)$ and its rock matrix ( $\rho m a)$

Neutron Log: The neutron log is sensitive mainly to the amount of hydrogen atoms in a formation. The tool operates by bombarding the formation with high energy neutrons. A source and two detectors are mounted in a tool, which is pressed against the borehole wall. The two detectors only count the returning neutrons which have a thermal energy level. From the ratio of thermal neutrons detected by the far and the near detector, the amount of the hydrogen $(\mathrm{H})$ atoms is empirically determined. The tool assumes $\mathrm{H}$ atoms to be present in the pore space (water or hydrocarbons).

Density/Neutron Combination: The densities and neutron tool both determine the porosity of a reservoir, but do this by measuring different quantities. The density tool measures the bulk density and The neutron tool measures the hydrogen density. For this reason, both tools react differently to certain pore fluids and lithologies. It is standard practice to plot both logs in one track using a scale such that both logs overlay in water bearing limestone. Using these scales, the logs will separate uniquely in other lithologies for example.In gas bearing zones the recorded is lower and the bulk density is reduced compared with the responses in similar water/oil bearing formation. These effects can be significant depending on the gas saturation in the invaded zone. The resulting (large) separation with neutron on the right and density on the left is called gas separation. This effect for a balloon shape and is therefore popularly known as the "Balloon Effect".

Evaluation of Lithology Identification: The gamma ray (GR) log was used to identify lithology. Within the $\log$ strip shale, on the right hand side, the GR level of the thickest shale bed is read which is assumed to represent a section that is $100 \%$ shale, and a straight line through these points is the shale line. Similarly, a sand line is constructed on the left hand side of the log strip, reading the average GR level of thick sands which is equivalent to sands with the lowest GR level.
For quick look evaluation a vertical line is drawn in between the shale and the sand line as is referred to as the cut-off line. All intervals where the GR log is on left are then assumed to be sandstone. For the wireline log used as a case study in the evaluation here, shale line was read at 100 API, while the sand line was read at 30 API, thus making a cut- off line at around 65 API. The level of the GR within a reservoir interval indicates the level of its shaliness, and is calculated as the volume of shale. This volume of shale in reservoir sand has an effect on the porosity, and is thus used in evaluating the effective porosity from the average porosity of a particular reservoir.

Evaluation of Porosity Determination: Porosity calculations were done using both density and neutron logs. The NPHI log (porosity) which was in limestone porosity units and this was corrected with neutron porosity correction chart (shown below) to get the true neurton porosity. Then porosity was also calculated using the density readings. After which certain formulas were applied to get the total porosity on the average of both logs. These formulas are given in the petrophysical parameters listed in one of the subsequent sub-headings of this chapter. Also, in other to check the consistency of the porosities, the bulk density ( $\rho b)$ and the neutron porosity (p.u) were plotted. The neutron-density cross plot (shown below) and porosity was estimated on each lithologic line. In gas bearing reservoirs where the neutron porosities are very low due to low density of $\mathrm{H}$ atoms in gas phase, this cross plot can also be used to correct the porosity of gas bearing reservoir by drawing a line through the plotted point parallel to the Approximate Gas Correction arrow.

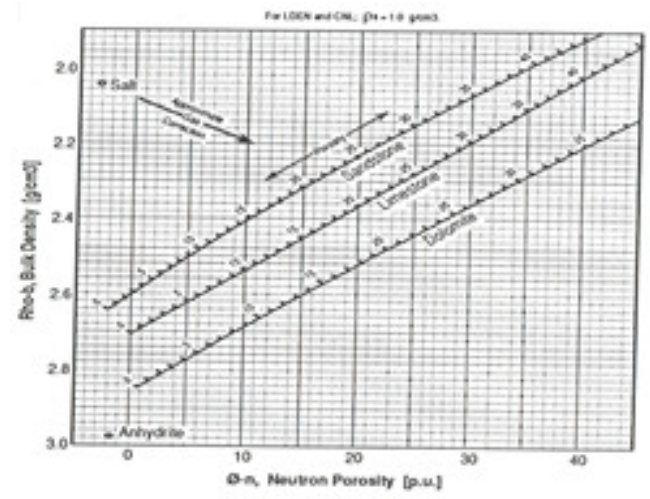

Fig. 5: Neutron-Density cross plot

After obtaining the total porosity, effective porosity was then determined, to remove the effect of shale within the reservoir sand. This effective porosity is the parameters used in most cases to determine other petrophysical properties such was water saturation, permeability, etc. 


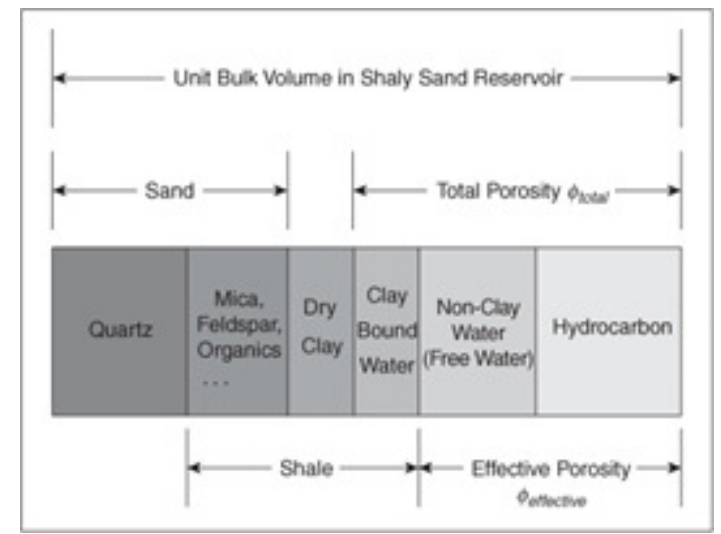

Fig. 6: Porosity model for a shaly sand reservoir (from Al-Ruwaili et al 2004)

Fluid Type Determination: The resistivity log was used to determine the kind of fluid in a sand reservoir (determined from the Gamma Ray $\log$ ), which basically can be either water or hydrocarbon. The log was calibrated on a logarithm scale between 0.2 and 2000ohm.m, thus making the different intervals to be $0.2,2,20,200$ and $2000 \mathrm{ohm} . \mathrm{m}$. Generally, water will show a low deep resistivity reading while hydrocarbons will give a high deep resistivity reading. Typically for the quick look evaluation of the case study wireline log. Any reservoir with resistivity reading higher than $20 \mathrm{ohm}$.m was assumed to contain hydrocarbon, while those less than 20ohm.m were taken to be water. But theoretically, these lesser resistivity readings that indicated water were observed to mostly be around 2ohm.m on the case study log. Furthermore, the type of hydrocarbon present at a particular interval (i.e. whether oil or gas) can also be determined by studying the separation of the porosity logs (neutron and density logs in this case) as explained in the neutron-density combination above. Therefore, identification of potential hydrocarbon reservoir intervals is by looking for the separation of resistivity curves in combination with GR and porosity logs.

Permeability Determination: Permeability is best determined from core analysis to get a more accurate result. But where core data is not available, such as in the case of this work, relative permeability can be calculated for quick-look evaluation purpose, using quantitative parameters such as porosity, water saturation, formation resistivity factor, bulk volume water, etc. Applying them to various equations or formulas such as those postulated by Timur (1968), Asquith and Krygowski (2004), etc. For this work, in order to determine the permeability of hydrocarbon bearing reservoirs, the Irreducible Water Saturation $\left(S_{\text {wirr }}\right)$ was first obtained. The Irreducible Water Saturation describes the water saturation at which all the water is absorbed on the grains in a rock or is held in capillaries by capillary pressure. It was calculated using the formation resistivity factor in an equation by Asquith and Krygowski (2004). After which the permeability was then calculated using Tumur's equation (both equations are shown in petrophysical parameters below).

Reservoir Sand Facies Classification: For the classification reservoir sand facie and depositional environment, the shapes of the gamma rays could be matched or compared with standard log models. In this case the model used was the Electrofacies classification for deltaic environments from Gamma Ray log, by World Energy Council (WEC), 1985.

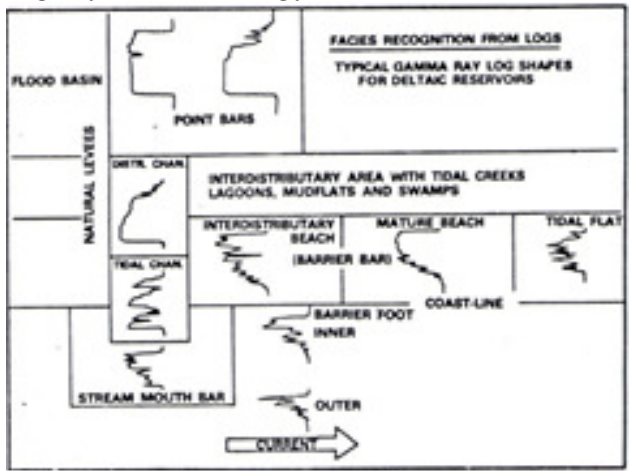

Fig. 7: Electro facies classification for deltaic environments from gamma ray logs (adapted from Schlumberger 1985)

Petrophysical Characteristics of the Reservoirs: The following petrophysical parameters were calculated and used for the hydrocarbon analysis of the study well.

1. $\quad$ Volume Of Shale (Vsh)

$$
\mathrm{Vsh}=\left[\frac{\mathrm{GRlog}-\mathrm{GRmin}}{\mathrm{GRmax}-\mathrm{GRmin}}\right]
$$

It is expressed in percentage i.e. multiplied by 100

Where; GRlog $=$ GR reading of the reservoir; GRmin $=\mathrm{GR}$ reading of sand line; GRmax $=\mathrm{GR}$ reading of shale line

\section{2. $\quad$ Porosity From Density Reading Or Density} Porosity $\left(\emptyset_{D}\right)$

$$
\varnothing_{\mathrm{D}}=\left[\frac{\rho \mathrm{ma}-\rho \mathrm{b}}{\rho \mathrm{ma}-\rho \mathrm{f}}\right] \times 100
$$

Where; $\rho$ ma $=$ Density of matrix material $(2.65$ for sand); $\rho b=$ Bulk density reading of reservoir read from log; $\rho \mathrm{f}=$ Density of contained fluid ( 1 for water, and $\mathrm{O} .85$ for oil) 
3. Porosity From Combination Of Neutron And 8. Density $(\varnothing)$

For Oil or Waters Zones; $\varnothing=\frac{\emptyset_{D}+\emptyset_{N}}{2}$

$$
\text { For Gas Zones; } \emptyset=\frac{2 \emptyset_{\mathrm{D}}+\emptyset_{\mathrm{N}}}{3}
$$

Where; $\emptyset_{\mathrm{N}}=$ Corrected neutron porosity

4. Effective Porosity (Øe)

$$
\varnothing \mathrm{e}=\varnothing-(1-\mathrm{Vsh})
$$

5. Formation Resistivity Factor $(F)$

$$
\mathrm{F}=\frac{a}{\emptyset^{m}}
$$

Where; $m$ is taken as 2 , and a is taken as 1 (both constants)

\section{Water Saturation ( $S w)$}

$$
\mathrm{SW}^{\mathrm{n}}=\frac{a \times R w}{\emptyset^{m} \times R t}
$$

Where; $\mathrm{n}=$ saturation exponent and taken as 2

$$
\text { Thus Sw }=\sqrt{\frac{F \times R w}{R t}}
$$

Where; Rt $=$ Resistivity of hydrocarbon bearing formation ( $\mathrm{read}$ from the $\mathrm{log}$ ); $\mathrm{Rw}=$ Formation water resistivity

Note: Rw is usually constant and is best determined from core data, but can be calculated in the absence of core data and for quick look evaluation, in which case it become Apparent Formation Water Resistivity. It can be calculated from a water-bearing reservoir sand (preferably the thickest) using the formula below (derived from Archie's first equation);

$$
\mathrm{Rwa}=\emptyset^{m} \times R o
$$

Where Ro = Resistivity of water bearing formation (read from the log).

Thus the Rwa used during the course of this work was calculated from Reservoir 12 and was given as 0.19 ohm.m

\section{Hydrocarbon Saturation (Shc)}

$$
\mathrm{Shc}=(1-\mathrm{Sw}) \times 100
$$

8. Bulk Volume Of Water $(B V W)$

$$
\mathrm{BVW}=\mathrm{Sw} \times \emptyset \mathrm{e}
$$

9. $\quad$ Irreducible Water Saturation $\left(S_{\text {wirr }}\right)$

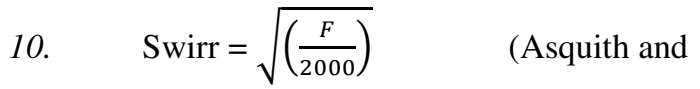

Krygowski, 2004)

$$
\begin{aligned}
& \text { 11. Permeability }(K) \\
& \mathrm{K}(\mathrm{md})=0.136 \frac{\varnothing \mathrm{e}^{4.40}}{\text { Swirr }^{2}} \quad \text { (Tumur, 1968) }
\end{aligned}
$$

\section{RESULT AND DISCUSSION}

The well $\log$ analyzed contains of sandstone reservoirs. Various petrophysical properties as given above in the previous chapter were calculated at different depth intervals and zones within the wells are shown in table $2 \mathrm{a}$ and $2 \mathrm{~b}$. The facie type for the reservoir sand that contained hydrocarbon are given in the table 3

Table 3: Hydrocarbon Bearing Reservoir Sand Facie Types

\begin{tabular}{|l|l|}
\hline Reservoir Sand & Facie Types \\
\hline $27 \mathrm{a}$ & Tidal Flat \\
\hline 31 & Tidal Flat \\
\hline 32 & Tidal Flat \\
\hline $33 \mathrm{a}$ & Distributary Channel \\
\hline 37 & Tidal Flat \\
\hline 38 & Tidal Flat \\
\hline 39 & Tidal Flat \\
\hline 40 & Distributary Channel \\
\hline $41 \mathrm{a}$ & Stream Mouth Bar \\
\hline $44 \mathrm{a}$ & Distributary Channel \\
\hline
\end{tabular}

Summary: NET SAND (total sand thickness) $=958 \mathrm{~m} ; \mathrm{NET} /$ GROSS = 958/1950 = 0.49; OWC =2288m, 2518m, 2989m; GOC = None $G W C=$ None $;$ NET PAY THICKNESSES $=238 \mathrm{~m}$ (Oil only)
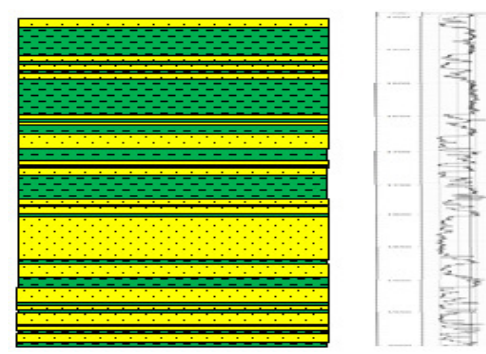

Fig 8a: A Profile Section of Well $\mathrm{X}$
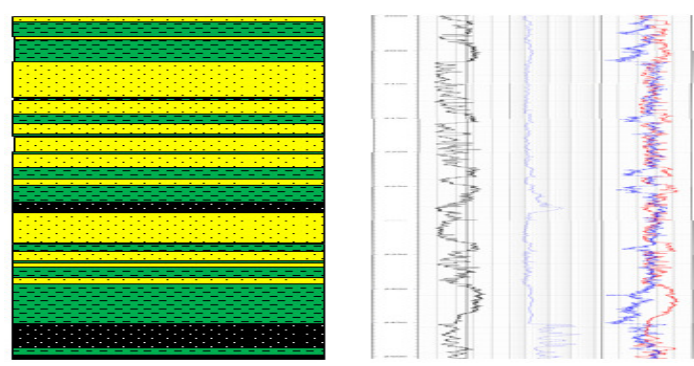

Fig 8b: A Profile Section of Well X (Cont'd) 
Table 2A: Well ' $\mathrm{X}$ ' Petrophysical Evaluation

\begin{tabular}{|c|c|c|c|c|c|c|c|c|}
\hline $\begin{array}{l}\text { Sand } \\
\text { Unit }\end{array}$ & $\begin{array}{l}\text { Depth } \\
\text { (m) }\end{array}$ & $\begin{array}{l}\text { Thick- } \\
\text { ness } \\
(\mathrm{m})\end{array}$ & $\begin{array}{l}\text { Fluid } \\
\text { Present }\end{array}$ & $\begin{array}{l}\text { HLLD } \\
\text { (Ro/Rt) } \\
\text { Ohm/m }\end{array}$ & $\begin{array}{l}\text { RHOZ } \\
\left(\mathrm{g} / \mathrm{cm}^{3}\right)\end{array}$ & $\begin{array}{l}\emptyset_{\mathrm{D}} \\
(\%)\end{array}$ & $\begin{array}{l}\text { TNPH } \\
\left(\emptyset_{\mathrm{N}}\right) \\
(\%) \\
\end{array}$ & $\begin{array}{l}\text { Corrected } \\
\emptyset_{\mathrm{N}} \\
(\%)\end{array}$ \\
\hline 1 & $1500-1515$ & 15 & Water & 1.8 & 2.15 & 30.3 & 30.0 & 34.0 \\
\hline 2 & $1558-1567$ & 9 & Water & 2.0 & 2.18 & 28.5 & 28.0 & 32.0 \\
\hline 3 & $1570-1580$ & 10 & Water & 1.6 & 2.10 & 33.3 & 34.0 & 38.5 \\
\hline 4 & $1584-1593$ & 9 & Water & 1.7 & 2.12 & 32.1 & 32.0 & 37.0 \\
\hline 5 & $1647-1654$ & 7 & Water & 1.9 & 2.05 & 36.4 & 32.0 & 37.0 \\
\hline 6 & $1659-1664$ & 5 & Water & 1.8 & 2.10 & 33.3 & 32.0 & 37.0 \\
\hline 7 & $1678-1700$ & 22 & Water & 1.8 & 2.10 & 33.3 & 33.0 & 37.5 \\
\hline 8 & $1717-1725$ & 8 & Water & 1.9 & 2.15 & 30.3 & 28.0 & 32.5 \\
\hline 9 & $1729-1739$ & 10 & Water & 1.8 & 2.13 & 31.5 & 30.0 & 34.0 \\
\hline 10 & $1775-1785$ & 10 & Water & 1.8 & 2.10 & 33.3 & 30.0 & 34.0 \\
\hline 11 & $1788-1793$ & 5 & Water & 1.7 & 2.06 & 35.8 & 31.0 & 35.5 \\
\hline 12 & $1803-1868$ & 65 & Water & 1.9 & 2.15 & 30.3 & 29.0 & 33.0 \\
\hline 13 & $1875-1895$ & 20 & Water & 1.9 & 2.13 & 31.5 & 27.0 & 31.0 \\
\hline 14 & $1910-1934$ & 24 & Water & 2.2 & 2.16 & 29.7 & 27.0 & 31.0 \\
\hline 15 & $1938-1945$ & 7 & Water & 2.4 & 2.18 & 28.5 & 24.0 & 28.0 \\
\hline 16 & $1950-1967$ & 17 & Water & 2.2 & 2.15 & 30.3 & 25.0 & 29.5 \\
\hline 17 & $1970-1976$ & 6 & Water & 2.0 & 2.13 & 31.5 & 26.0 & 30.5 \\
\hline 18 & 1982-1995 & 13 & Water & 2.0 & 2.15 & 30.3 & 27.0 & 31.0 \\
\hline 19 & $2000-2007$ & 7 & Water & 1.9 & 2.13 & 31.5 & 28.0 & 32.5 \\
\hline 20 & 2029-2034 & 5 & Water & 2.2 & 2.14 & 31.0 & 27.0 & 31.0 \\
\hline 21 & $2067-2119$ & 52 & Water & 2.6 & 2.20 & 27.3 & 24.0 & 28.0 \\
\hline 22 & $2123-2143$ & 20 & Water & 2.2 & 2.13 & 31.5 & 26.0 & 30.5 \\
\hline 23 & $2157-2172$ & 15 & Water & 2.2 & 2.15 & 30.3 & 27.0 & 31.0 \\
\hline 24 & 2176-2199 & 23 & Water & 2.2 & 2.15 & 30.3 & 27.0 & 31.0 \\
\hline 25 & $2202-2221$ & 19 & Water & 2.4 & 2.18 & 28.5 & 26.0 & 30.5 \\
\hline 26 & $2238-2248$ & 10 & Water & 2.2 & 2.14 & 31.0 & 28.0 & 32.5 \\
\hline $27 \mathrm{a}$ & 2273-2288 & 15 & Oil & 20.0 & 2.15 & 27.8 & 18.0 & 22.5 \\
\hline $27 b$ & $2288-2333$ & 45 & Water & 2.6 & 2.20 & 27.3 & 24.0 & 28.0 \\
\hline 28 & $2345-2359$ & 14 & Water & 2.0 & 2.18 & 28.5 & 28.0 & 32.5 \\
\hline 29 & $2362-2368$ & 6 & Water & 2.0 & 2.17 & 29.1 & 26.0 & 30.5 \\
\hline 30 & $2384-2393$ & 9 & Water & 2.0 & 2.14 & 31.0 & 28.0 & 32.5 \\
\hline 31 & $2451-2486$ & 35 & Oil & 70.0 & 2.16 & 27.2 & 30.0 & 34.0 \\
\hline 32 & $2498-2503$ & 5 & Oil & 40.0 & 2.05 & 33.3 & 26.0 & 30.5 \\
\hline $33 a$ & $2508-2518$ & 10 & Oil & 50.0 & 2.10 & 30.6 & 20.0 & 24.0 \\
\hline $33 b$ & $2518-2545$ & 27 & Water & 2.2 & 2.20 & 27.3 & 24.0 & 28.0 \\
\hline 34 & $2563-2575$ & 12 & Water & 2.4 & 2.21 & 26.7 & 27.0 & 31.0 \\
\hline 35 & $2656-2668$ & 12 & Water & 2.0 & 2.20 & 27.3 & 28.0 & 32.5 \\
\hline 36 & $2702-2714$ & 12 & Water & 2.4 & 2.20 & 27.3 & 27.0 & 31.0 \\
\hline 37 & $2921-2930$ & 9 & Oil & 200.0 & 2.35 & 16.7 & 19.0 & 21.5 \\
\hline 38 & $2939-2945$ & 6 & Oil & 100.0 & 2.22 & 23.9 & 20.0 & 24.0 \\
\hline 39 & 2953-2970 & 17 & Oil & 600.0 & 2.25 & 22.2 & 18.0 & 22.5 \\
\hline 40 & 2973-2978 & 5 & Oil & 400.0 & 2.20 & 25.0 & 18.0 & 22.5 \\
\hline $41 \mathrm{a}$ & 2982-2989 & 7 & Oil & 80.0 & 2.25 & 22.2 & 20.0 & 24.0 \\
\hline $41 b$ & 2989-3018 & 29 & Water & 4.0 & 2.28 & 22.4 & 21.0 & 25.0 \\
\hline 42 & $3022-3078$ & 56 & Water & 3.0 & 2.22 & 26.1 & 24.0 & 28.0 \\
\hline 43 & $3085-3092$ & 7 & Water & 2.5 & 2.20 & 27.3 & 22.0 & 26.5 \\
\hline $44 a$ & $3253-3382$ & 129 & Oil & 1200.0 & 2.25 & 22.2 & 16.0 & 20.5 \\
\hline $44 \mathrm{~b}$ & $3382-3450$ & 68 & Water & 6.0 & 2.30 & 21.2 & 18.0 & 22.5 \\
\hline
\end{tabular}

Table 2B: Well ' $\mathrm{X}$ ' Petrophysical Evaluation continue

\begin{tabular}{|c|c|c|c|c|c|c|c|c|c|}
\hline $\begin{array}{l}\text { Sand } \\
\text { Unit }\end{array}$ & $\begin{array}{l}\emptyset \\
(\%)\end{array}$ & $\begin{array}{l}\text { Vsh } \\
(\%)\end{array}$ & $\begin{array}{l}\emptyset \mathrm{e} \\
(\%)\end{array}$ & $\mathrm{F}$ & $\begin{array}{l}\text { Sw } \\
(\%)\end{array}$ & $\begin{array}{l}\text { Shc } \\
(\%)\end{array}$ & BVW & $\begin{array}{l}S_{\text {wirr }} \\
(\%)\end{array}$ & $\begin{array}{l}\mathrm{K} \\
(\mathrm{md})\end{array}$ \\
\hline 1 & 32.2 & 14.3 & 27.6 & 9.7 & 100 & - & 27.6 & & \\
\hline 2 & 30.3 & 21.4 & 23.8 & 10.9 & 100 & - & 23.8 & & \\
\hline 3 & 35.9 & 17.1 & 29.8 & 7.8 & 100 & - & 29.8 & & \\
\hline 4 & 34.6 & 28.6 & 24.7 & 8.4 & 100 & - & 24.7 & & \\
\hline 5 & 34.2 & 21.4 & 26.9 & 8.6 & 100 & - & 26.9 & & \\
\hline 6 & 35.2 & 25.7 & 26.2 & 8.1 & 100 & - & 26.2 & & \\
\hline 7 & 35.4 & 4.3 & 33.9 & 8.0 & 100 & - & 33.9 & & \\
\hline 8 & 31.4 & 4.3 & 30.1 & 10.1 & 100 & - & 30.1 & & \\
\hline 9 & 32.8 & 7.1 & 30.5 & 9.3 & 100 & - & 30.5 & & \\
\hline 10 & 33.7 & 17.1 & 27.9 & 8.8 & 100 & - & 27.9 & & \\
\hline 11 & 35.7 & 28.6 & 25.5 & 7.9 & 100 & - & 25.5 & & \\
\hline 12 & 31.7 & 11.4 & 28.1 & 10.0 & 100 & - & 28.1 & & \\
\hline 13 & 31.3 & 22.9 & 24.1 & 10.2 & 100 & - & 24.1 & & \\
\hline 14 & 30.4 & 14.3 & 26.1 & 10.8 & 100 & - & 26.1 & & \\
\hline 15 & 28.3 & 11.4 & 25.1 & 12.5 & 100 & - & 25.1 & & \\
\hline 16 & 29.9 & 4.3 & 28,6 & 11.2 & 100 & - & 28,6 & & \\
\hline 17 & 31.0 & 18.8 & 25.2 & 10.4 & 100 & - & 25.2 & & \\
\hline 18 & 30.7 & 17.1 & 25.5 & 10.6 & 100 & - & 25.5 & & \\
\hline 19 & 32.0 & 18.8 & 26.0 & 9.8 & 100 & - & 26.0 & & \\
\hline 20 & 31.0 & 15.7 & 26.1 & 10.4 & 100 & - & 26.1 & & \\
\hline 21 & 28.3 & 20.0 & 22.2 & 13.0 & 100 & - & 22.2 & & \\
\hline 22 & 31.0 & 27.1 & 22.6 & 10.4 & 100 & - & 22.6 & & \\
\hline 23 & 30.7 & 14.3 & 26.3 & 10.6 & 100 & - & 26.3 & & \\
\hline
\end{tabular}

IGHODARO, EJ; OKANIGBUAN, PN; OKIOTOR, ME; IDEMUDIA, $N$ 


\begin{tabular}{llllllllll}
\hline 24 & 30.7 & 28.6 & 21.9 & 10.6 & 100 & - & 21.9 & & \\
25 & 29.5 & 31.4 & 20.2 & 11.5 & 100 & - & 20.2 & & \\
26 & 31.8 & 21.4 & 25.0 & 9.9 & 100 & - & 25.0 & & 3387 \\
$27 \mathrm{a}$ & 26.4 & 21.4 & 20.8 & 14.4 & 37 & 63 & 7.8 & 8.5 & \\
$27 \mathrm{~b}$ & 27.8 & 14.3 & 23.8 & 12.9 & 100 & - & 23.8 & & \\
28 & 30.5 & 35.1 & 19.8 & 10.8 & 100 & - & 19.8 & & \\
29 & 29.8 & 21.4 & 23.4 & 11.3 & 100 & - & 23.4 & & \\
30 & 31.8 & 22.9 & 24.5 & 9.9 & 100 & - & 24.5 & & \\
31 & 31.9 & 18.6 & 26.0 & 9.8 & 16.3 & 83.7 & 4.2 & 7.0 & 11482 \\
32 & 33.5 & 31.4 & 23.0 & 8.9 & 20.6 & 79.4 & 4.7 & 6.7 & 15545 \\
$33 \mathrm{a}$ & 28.7 & 14.3 & 24.6 & 12.1 & 21.4 & 78.6 & 5.3 & 7.8 & 5808 \\
$33 \mathrm{~b}$ & 27.7 & 14.3 & 23.7 & 13.0 & 100 & - & 23.7 & & \\
34 & 28.9 & 21.4 & 22.7 & 12.0 & 100 & - & 22.7 & & \\
35 & 29.9 & 37.1 & 18.8 & 11.2 & 100 & - & 18.8 & & \\
36 & 27.2 & 35.7 & 17.5 & 13.5 & 100 & - & 17.5 & & \\
37 & 19.9 & 28.6 & 14.2 & 25.3 & 15.5 & 84.5 & 2.2 & 11.2 & 562 \\
38 & 25.1 & 22.9 & 19.4 & 15.9 & 17.4 & 82.6 & 3.4 & 8.9 & 2474 \\
39 & 23.4 & 14.3 & 20.1 & 18.3 & 7.6 & 92.4 & 1.5 & 9.6 & 1562 \\
40 & 24.9 & 25.7 & 18.5 & 16.1 & 8.8 & 91.2 & 1.6 & 9.0 & 2335 \\
$41 \mathrm{a}$ & 23.4 & 14.3 & 20.1 & 18.3 & 20.9 & 79.1 & 4.2 & 9.6 & 1562 \\
$41 \mathrm{~b}$ & 23.7 & 28.6 & 16.9 & 17.8 & 100 & - & 16.9 & & \\
42 & 27.1 & 21.4 & 21.3 & 13.6 & 100 & - & 21.3 & & \\
43 & 26.3 & 17.1 & 21.8 & 14.5 & 100 & - & 21.8 & & \\
$44 \mathrm{a}$ & 22.5 & - & 22.5 & 19.8 & 5.6 & 94.4 & 1.3 & 10.0 & 1211 \\
$44 \mathrm{~b}$ & 21.9 & - & 21.9 & 20.9 & 100 & - & 21.9 & & \\
\hline & & & & & & & & &
\end{tabular}
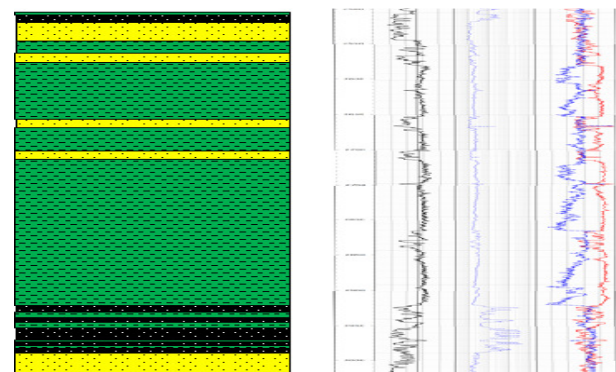

Fig 8c: A Profile Section of Well X (Cont'd)
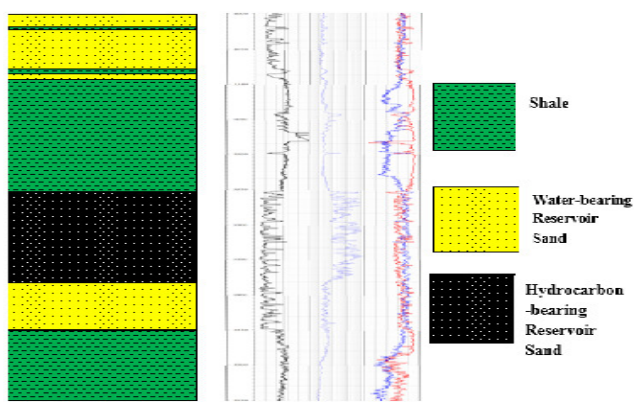

Fig 8d: A Profile Section of Well X (Cont'd)

Hydrocarbon occurred at reservoir zones 27a, 31, 32, 33a, 37, 38, 39, 40, 41a, 44. Water bearing zones generally show a low resistivity of about $20 \mathrm{hm}$.m in average. This is due to the high conductive nature of water. The volume of shale in each reservoir zone is observed to directly affect the effective porosity and the zones. The volume of shale is inversely proportional to the effective porosity, as an increase in the volume of shale will bring about a decrease in effective porosity. On the other hand, permeability is dependent on the effective porosity. When matched with the values used for reservoir qualitative description (adapted from Rider, 1986), the porosity values range from good to excellent, while the permeability values range from very good to excellent.

Table 4: Qualitative Evaluation of Porosity (Adapted from Rider,

\begin{tabular}{ll} 
& $1986)$ \\
\hline Percentage Porosity & Qualitative Description \\
\hline $0-5$ & Negligible \\
$5-10$ & Poor \\
$15-20$ & Good \\
Over $20-25$ & Very Good \\
Over 30 & Excellent \\
\hline
\end{tabular}

Table 5: Qualitative Evaluation of Permeability (Adapted from Rider, 1986)

\begin{tabular}{ll}
\hline Average K- value (md) & Quantitative Description \\
\hline$<10.5$ & Poor to Fair \\
$15-50$ & Moderate \\
$50-250$ & Good \\
$250-1000$ & Very Good \\
$>1000$ & Excellent \\
\hline
\end{tabular}

Hydrocarbon occurred in basically three (3) types of sandstone depositional facies, which includes; Tidal flats, Distributary channels, and Stream mouth bar. The total net pay thickness for gas is $238 \mathrm{~m}$ and is mainly dominated by oil. It is important to note that results acquired from a critical petrophysical evaluation of well logs only give a theoretical view of such well.

Conclusion: In conclusion, for the production and development of the well, it can be said that all the hydrocarbon zones are producible since they all have hydrocarbon saturations greater than $60 \%$ and have from very good to excellent permeability values.

\section{REFERENCES}

Al-Ruwaili, S.A, and Al-Waheed, H.H (2004): "Improved Petrophysical Methods and 
Techniques for Shaly Sands Evaluation," paper SPE 89735 presented at the 2004 SPE International Petroleum Conference in Puebla.

Benkhelil, J. (1989). "The Origin and Evolution of the Cretaceous Benue Trough (Nigeria)". Journal of African Earth Sciences. 8:251-282.

Bullard, E.C, Everett, J.E, and Smith, A.G (1965). "Fit of the Continents around the Atlantic". Philosophical Transactions of the Royal Society London A. 258:41-51.

Burke, K.C, (1996). The African Plate: South African Journal of Geology, vol. 99, p. 341-409

Burke, K.C., Dessauvagie, T.F.J., Whiteman, A.J., (1971). The Opening of the Gulf of Guinea and the Geological History of the Benue Depression and Niger delta. Nature Physical Science 233, 5155 .

Doust, H., and Omatsola, E., (1990). Niger Delta, in, Edwards, J. D., and Santogrossi, P.A., eds., Divergent/passive Margin Basins, AAPG Memoir 48: Tulsa, American Association of Petroleum Geologists, p. 239-248.

Ejedawe, J.E, (1981). Patterns of Incidence of Oil Reserves in Niger Delta Basin: American Association of Petroleum Geologists, v. 65, p. 1574-1585.

Evamy B.D, Haremboure J., Kamerling P., Knaap W.A, Molloy F. A and Rowlands P.H, (1978). Hydrocarbon habitat of Tertiary Niger Delta: American Association of Petroleum Geologists Bulletin, vol. 62, p. 277-298.

Fairhead, J.D and Green, C.M (1989). "Controls on Rifting in Africa and the Regional Tectonic Model for the Nigeria and East Niger Rift Basins". Journal of African Earth Sciences. 8:231-249.

Guiraud, R. and Bellion, Y. (1995). "Late Carboniferous to Recent Geodynamic Evolution of the West Gondwanian, Cratonic, Tethyan Margins". In: Nairn, A.E.M. et al. (eds.). The Ocean Basins and Margins (8), The Tethys Ocean. 101-124.
King, L.C (1950). "Outline and Disruption of Gondwanaland”. Geological Magazine. 87:353359.

Knox, G.J and Omatsola, M.E, (1987). Development of the Cenozoic Niger Delta in terms of Escalator Regression Model. [In:] Proceedings of the KNGMG Symposium 'Coastal Lowlands Geology and Geotechnology’. Kluwer Academic Publisher, 181-202.

Murat, R.C, (1972). Stratigraphy and Paleogeography of the Cretaceous and Lower Tertiary in Southern Nigeria. In: Dessauvagie, T.F.J., Whiteman, A.J. (Eds.), Africa

Obi, G.C, Okogbue, C.O, and Nwajide, C.S (2001). "Evolution of the Enugu Cuesta: A Tectonically Driven Erosional Process." Global Journal of Pure Applied Sciences. 7:321-330.

Reyment, R.A, (1965). In: Aspects of the Geology of Nigeria. University of Ibadan Press: Ibadan, Nigeria. 145.

Reyment, R.A (1969). “Ammonite Biostratigraphy, Continental Drift and Oscillatory Transgressions". Nature. 224:137-269.

Rider M., (1986). "The Geological Interpretation of Well Logs”, Blackie, Glasgow, pp. 151-165.

Short, K.C and Stauble, A.J (1967). Outline Geology of the Niger Delta. American Association of Petroleum Geologists Bulletin 51, 761-779.

Schlumberger (1989). Log interpretation, Principles and Application: Schlumberger Wireline and Testing, Houston Texas.

Stacher, P. (1995). Present Understanding of the Niger Delta Hydrocarbon Habitat, in Oti, M. N. and Postma, G., eds., Geology of Deltas: Rotterdam, A.A. Balkema, p. 257-267. 